Irina Mashrina, Konstantin Lidin, Timofey Baranov

Irkutsk State Transport University, Russia

\title{
Intellectual capital management in a university
}

The end of the $20^{\text {th }}$, and the first decade of this century have been characterized by the rapid development of a new area of economy - the knowledge economy. A phenomenon of intangible assets and their major varieties - intellectual capital (IC) - has convincingly proved to be effective on the example of many rapidly growing companies, like Microsoft, Apple, etc. (Bruking 2001). Thus, according to T. Stewart (1997), the total capitalization of Microsoft was \$ 85.5 billion, while the residual value of fixed capital was only \$ 930 million (Stewart 1997). The intellectual capital comprised over eighty percent of the total capital of the company.

Since the nineties of the twentieth century, a number of techniques for IC measuring have appeared. The simplest of them is Market Capitalization Methods (MCM). The difference between the market capitalization of the company and its shareholders equity is calculated. The value obtained is considered to be the value of its intellectual capital or intangible assets. Intellectual capital may be calculated by other ways: Return on Assets methods (ROA), Scorecard Methods (SC), etc. (Romanteev 2011). However, most of these techniques cannot be applied in Russian business (Leontiev 2002). Especially great methodological difficulties are connected with attempts to measure IC of institutions of higher education.

In the Siberian region, Irkutsk State Transport University is a young transport university with perspectives. The University graduates work in many areas of the economy and are highly regarded by employers. High competitive pressure from larger and older universities of Irkutsk creates the need to seek competitive advantages. Intellectual capital of the University can serve as one of them.

To evaluate the intellectual capital of the university, a modified model of capital structure was used, proposed by a major American expert, Leif Edvinsson (Edvinsson 2005). In this model, the intellectual capital is represented as the arithmetic sum of its elements. It is proposed to determine the level of commercialization in a unified coordinate system, where the coordinates represent monetary values of certain components (Fig. 1). 
According to the structure for human capital (HC) elaborated by the authors of this article, $\mathrm{HC}$ is understood as the competence and abilities of the company personnel. In our case, it is the entire faculty and staff of the University.

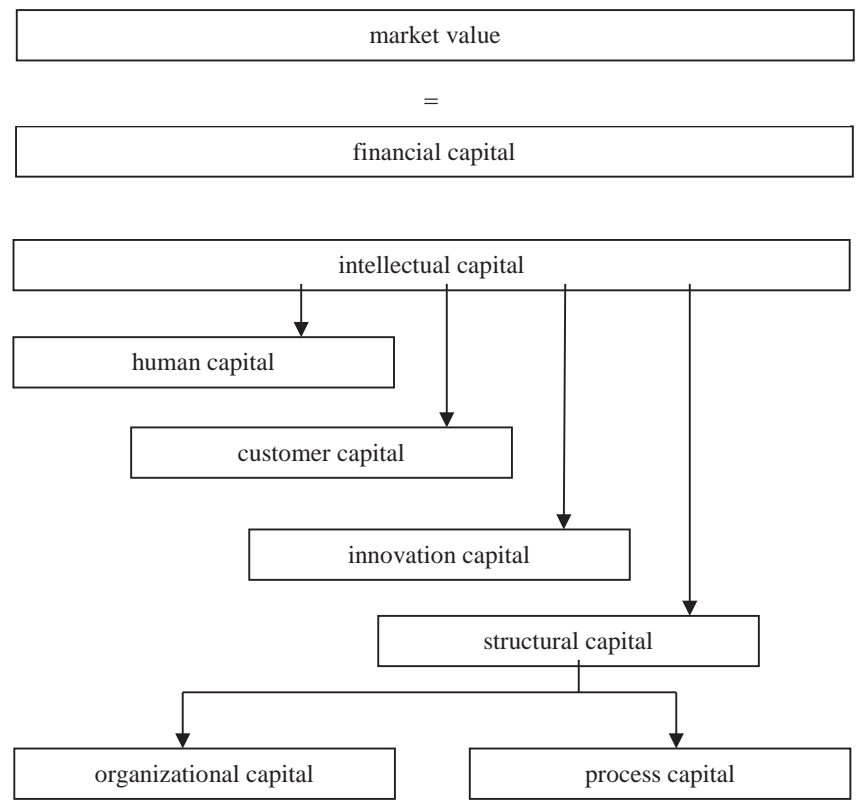

Fig. 1. IC components

It is believed that, to find an employee through a recruitment agency, a company must pay an amount equal to the monthly salary of the employee, for the services of the agency. We take that the average salary among the faculty is 20 thousand rubles, while for the staff it is 12 thousand rubles. The total faculty of the University comprises 398 persons, the staff 200 persons. So, the entire human capital is estimated slightly over 10 million rubles.

Customer capital (CC) represents the value enclosed in the relationships with the customers. Major clients consuming the service of the University are students. The capital is the sum of expenditures for selection committee and promotional campaign teams' activity, for advertising, etc. The expenditures must be calculated for the whole training term, until the educational services are completed. When calculating the actual visible advertising costs and personnel salaries, the customer capital is estimated at a little over 6 million rubles.

Innovation Capital (IC) consists primarily of the legal rights (patents, license agreements). Innovation Capital includes all training materials, textbooks, and monographs issued by the university faculty. The net value of a patent is determined by the cost of its maintenance. The cost of the teaching faculty publications is determined through multiplying the normative time for fulfilment of one manual by a teacher's one hour salary. So, the size of the University innovation capital is 20.5 million rubles. 
Structural capital (SC) in our model combines two components: the organizational capital (the system of normative documents and of the documents circulation order) and the process capital. In general, the structural capital is the system of relationships between personnel who provide the organization work. To understand the value of the University structural capital, we can use the method of thought experiment: suppose that all the structural communications within the organization are lost, and for their normal work it is necessary to restore them again.

According to experts' estimations, restoring the order of communications between the organization divisions (taking the number of officers to be 150 persons) would require 1 year. So, the organizational capital of the University can be estimated at 63 million rubles.

The Process Capital is the organization infrastructure. In the University, it is the software purchased. Totally, the University possesses the software worth about 50 million rubles.

\begin{tabular}{|c|c|c|c|}
\hline \multicolumn{2}{|c|}{ Intellectual Capital } & $\begin{array}{l}\text { Capital value, } \\
\text { thousand rubles }\end{array}$ & Part of each capital, \% \\
\hline \multicolumn{2}{|c|}{ Human (HC) } & 10360 & 7 \\
\hline \multicolumn{2}{|c|}{ Customer (CC) } & 6080 & 4 \\
\hline \multicolumn{2}{|c|}{ Innovation (IC) } & 20462 & 14 \\
\hline \multirow{2}{*}{ Structural } & Organizational & 63360 & 42 \\
\hline & Process & 50000 & 33 \\
\hline \multicolumn{2}{|l|}{ Total } & 150262 & 100 \\
\hline
\end{tabular}

Thus, according to this model, the intellectual capital of the university is estimated at 150 million rubles. A large proportion of this amount belongs to infrastructure and organizational cooperation (Fig. 2).

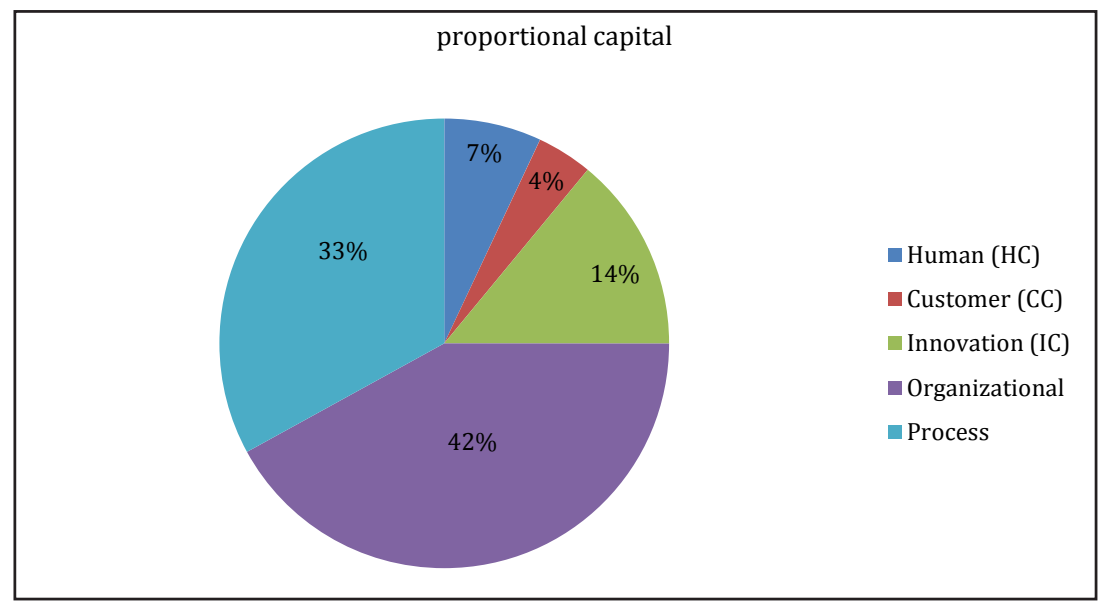

Fig. 2. The proportions of intellectual capital 
It is possible to influence each component of intellectual capital for a more complete and efficient use of this part of the capital. A thoughtful list of measures - together with identifying specific actions, not just directions of work - for all the components will be a real programme of the organization development in the field of intellectual capital.

Let us consider the two components of the intellectual capital which are directly related to the personnel of the organization: human capital and customer capital.

The quality of human capital in a high school is characterized by the proportion of persons with academic degrees among the faculty. Here, the defining characteristic is the rate of turnover of intellectual capital, as for any other type of a company capital. The capital is understood here as the resources circulating in the process of production. The characteristic of the level of capital use is the product of circulation velocity of intellectual capital by its amount.

Increasing the amount of intellectual capital due to obtaining an academic degree is equal to the difference in salaries without the degree and with it, all else being equal. Average monthly salary of a "docent" is 20 thousand rubles, the one of a senior teacher - 10 thousand rubles. Consequently, the increase in commercialization of the human capital is 10 thousand rubles per one person having obtained the degree. This is only growth of capital amount. In this case, additional human resources in the form of a new degree obtained are invested in producing new human resources - postgraduate students. Each $\mathrm{PhD}$ can supervise up to 5 such students, thereby increasing the intellectual capital in its human component still more.

So, the increase of human capital amount will be

$$
\Delta \mathrm{HC}=\Delta \mathrm{P}_{\mathrm{n \Pi c}}+\left(5 \mathrm{P}_{\mathrm{acm}}+\Delta \mathrm{P}_{\mathrm{n} \Pi \mathrm{c}}^{\mathrm{acn}}\right) \cdot \mathrm{t},
$$

where $\triangle \mathrm{HC}$ is - increasing commercialization of intellectual capital in terms of $\mathrm{HC}$ for one person, thousand rubles;

$\Delta \mathrm{P}_{\text {ппс }}$ - change in salary as the result of obtaining the degree, thousand rubles;

$\mathrm{P}_{\text {acп }}$ - salary and fellowships;

$\Delta \mathrm{P}_{\text {пाп }}^{\text {acn }}$ - addition to the docent's salary for supervising post-graduate students, thousand rubles per month;

$\mathrm{t}$ - duration of post-graduate training, months.

Thus, the increase in the intellectual capital value reaches 1.18 million rubles.

One of the additional parts of the system of employees' motivation is additional paid vacation to defend the thesis. The vacation lasts throughout the year, according to the Statute of the University, Article 6.19.

Suppose an employee takes a year vacation to write and defend the thesis, obtaining his actual average senior teacher salary of 10 thousand rubles per month. Then the expenses of the organization will make, obviously, 120 thousand rubles. After the vacation, the commercialization of intellectual capital increases in three years at1180 rubles.

Profitability $(\mathrm{R})$ of this event is defined as income or capital increase of the organization divided by expenditures.

$$
\begin{aligned}
& R=\frac{\Delta H C}{P_{n n c} \cdot 12} \\
& R=\frac{1180}{10 \cdot 12}=9,8
\end{aligned}
$$


In three years, profitability will be about 10 times.

The second component of intellectual capital is customer capital CC. In this model, only the expenditures for selection committee and promotional campaign teams' activity, including advertising, are taken into account. While the increase amount of this type of capital is debatable, the increase of the rate of its turnover is a completely solvable task.

Utilization level of capital (P) is the product of capital amount by its rate of turnover and profit margin for each turnover of capital.

$$
P=C C \cdot \tau \cdot n_{p}
$$

where $\tau$ - rate of capital turnover, times per year;

$n_{p}$ - the rate of profit.

Currently, customer capital of the University turns once every five years. It is proposed to make students combine training and practical activities, or to create favourable conditions for such combining. These activities can start with the fourth year of study, say, from the summer practice of the third year. The rate of return would be the relative difference between salaries of workers without education and with incomplete higher education.

The frequency of turnover will be reduced to once every three years. The relative amount of capital gains

$$
\varepsilon=\frac{P+\Delta P}{P},
$$

where $\Delta \mathrm{P}$ is absolute growth of human capital, defined by

$$
\Delta P=K n_{p}\left(\tau_{2}-\tau_{1}\right),
$$

where $\tau_{1}$ - current rate of capital turnover, times/year;

$\tau_{2}$ - the proposed rate of capital turnover, times/year

In our case, the growth of intellectual capital is $20 \%$.

The example demonstrates high effectiveness of measures taken in the sphere of commercialization of intellectual capital. With the approaches to intellectual capital as an asset of the organization in general, there appears to be a considerable rate of its turnover. Knowledge as a starting point of intellectual capital begins to generate new knowledge, increasing not only its amount but also its quality. A chain reaction starts, raising the level of commercialization of knowledge, thereby increasing the competitiveness of the university as a whole.

Unfortunately, publications on the questions of measurement of the higher education institutions IC, taking into account the specificity of Russian universities, appear quite seldom (Ivanov 2010). The proposed concrete variants for management practices of IC are usually tied to the peculiarities of the university for which they were elaborated (Tsurikov 2008). We should also note a number of papers in which only some of the components of the IC of the university are analyzed in detail (Romashkina 2009). In general, it can be argued that this issue is only in the early period of its study, which should become as broad and deep as the problem deserves it. 


\section{References}

Bruking E., 2001, Intellectual capital, trasl. by L.N. Konovalik, Spb: Piter, 288 p.

Edvinsson L., 2005, Corporate longitude. Navigating in an economy based on knowledge. Moscow: Infra-M, $252 \mathrm{p}$.

Ivanov V., 2010, Valuation of intellectual capital institutions of higher education//Problems of the modern economy, No 4 (36), p. 132-141.

Leontiev B., 2002, Price of intelligence. Intellectual capital in the Russian business, Moscow: Publishing Center "shareholder", $200 \mathrm{p}$.

Romanteev P.V., 2011, Analytical review of methods for assessing intellectual capital//The economy, Business and Law, No 3, 36-48p.

Romashkina R.K., 2009, Valuation of intellectual property institutions//Herald NGUEU, No 1, p. 33-41.

Stewart T.A., 1997, Intellectual Capital. The New Wealth of Organizations. N.Y.-L., Doubleday/ Currency.

Tsurikov S.V., 2008, Assets Predictive universities - one factor innovative development//Formation, No. 1, p. 112-116.

\section{Intellectual capital management in a university}

The notion of intellectual capital (IC) has proved to be crucial in determining the rating of a company. Particularly great methodological difficulties are connected with attempts to measure IC of institutions of higher education. The structure of IC is proposed, and the amount of each component is calculated on the example of the Irkutsk State Transport University.

Doc. Dr Konstantin Lidin, Dr Irina Mashkina, Timofey Baranov

Irkutsk State Transport University, Russia

e-mail: lidink1@hotmail.com; ro-mashkina@yandex.ru; Baranov-87@yandex.ru 